\title{
Separation of whey components by using ceramic composite membranes
}

\author{
İlker Erdem*, Muhsin Çiftçioğlu, Şebnem Harsa \\ İzmir Institute of Technology, Faculty of Engineering, Gülbahçe, 35430, Urla, İmir, Turkey \\ Tel.+90 (232) 7506322; Fax+90 (232) 7506196; email: ilkererdem@iyte.edu.tr
}

Received 20 April 2005; accepted 25 June 2005

\begin{abstract}
Ceramic supports were prepared from alumina powder and dip-coated with zirconia sol. The ceramic composite membranes prepared were characterized with respect to their microstructure/pore structures. The supports were $40 \%$ porous of which $87 \%$ were open pores. The average particle size of the sol particles was $35 \mathrm{~nm}$. The prepared membrane has good protein lactose separation properties with a relatively high protein content (PR $\sim 80 \%)$ and with relatively low lactose retention (LR 7\%). The permeate flux value was around $401 / \mathrm{m}^{2} \mathrm{~h}$. These results indicate the possibility of the preparation of ceramic composite membranes for separation of whey components with higher yields.
\end{abstract}

Keywords: Ceramic membrane; Ultrafiltration; Whey; Protein; Lactose; Alumina; Zirconia

\section{Introduction}

Production of $10-20 \mathrm{~kg}$ of cheese yields $80-$ $90 \mathrm{~kg}$ of whey. Whey consists of proteins $(\sim 1 \%)$, carbohydrates ( $\sim 5 \%$ lactose) and minerals $(0.5 \%$ $\mathrm{Ca}, \mathrm{K}, \mathrm{Mg}$, etc.). Utilization of whey towards the production of value-added products will be economical and environmentally desirable. The use of membrane processes in the fractionation of whey components is advantageous since high

*Corresponding author. temperatures are not involved that may increase cost while decreasing product quality. Ceramic membranes possess desirable properties in comparison with polymeric membranes. They are better choices economically due to their higher chemical, physical, thermal and microbiological stability which allows longer service life [1-3]. Rektor and Vatai [4] investigated membrane filtration of mozzarella whey by using commercial ceramic and polymeric membranes and suggested routes for whey treatment. Caric et al. [5]

Presented at the 10th Aachen Membrane Colloquium, 16-17 March 2005, Aachen, Germany. 
investigated the fouling mechanism of two commercial ceramic membranes made of zirconia and alumina which have pore sizes of 50 and $200 \mathrm{~nm}$, respectively. They reported the alumina membrane with larger pores was more susceptible to fouling.

Ceramic composite membranes were prepared and their microstructure/pore structures were characterized in this study. The effects of both the preparation of ceramic composite membranes and filtration process parameters on the separation of whey components were also investigated.

\section{Experimental}

\subsection{Materials}

Alumina powder (Alcoa CT3000SG) with $\mathrm{D}_{50}$ : $0.7 \mu \mathrm{m}$, starch and dispersing agents (e.g. DarvanC) were used for the preparation of ceramic supports. Zirconium propoxide (70\% in propanol), propanol, nitric acid and deionised water were used for preparing ceramic sols. Whey powder obtained from a local cheese manufacturer (Pinar Süt A.Ş., İzmir, Turkey) was dispersed in deionised water $(\sim 75 \mathrm{~g} / \mathrm{l})$ for testing the separation efficiency of the membranes.

\subsection{Preparation of ceramic composite membranes}

Ceramic composite membranes were prepared in two steps. Ceramic supports were prepared by slip-casting in the first step and the formation of thin selective layers over these supports was accomplished by dip-coating in the second step. Ceramic slips were prepared by dispersing the alumina powder with or without pore-forming agent (starch) in water via a dispersing agent. Ceramic supports were prepared by pouring ceramic slips into cylindrical plastic dies over plaster of Paris blocks. These ceramic discs were heat treated at $1300^{\circ} \mathrm{C}$ for $2 \mathrm{~h}$ with a heating rate of $10^{\circ} \mathrm{C} / \mathrm{min}$.

Ceramic sols were prepared by starting with zirconium propoxide, propanol, nitric acid and water with molar ratios $1 / 13.31 / 0.826 / 2$, respectively [6]. These zirconia sols were used as prepared [7] and aged for about a year in a refrigerator. Ceramic supports were dip-coated with the sols for $10 \mathrm{~s}$ and dried at ambient temperature. Then the coated supports were heat treated at $500^{\circ} \mathrm{C}$ for $2 \mathrm{~h}$ with a heating rate of $5^{\circ} \mathrm{C} / \mathrm{min}$.

\subsection{Characterization of ceramic composite mem- branes}

The porosities of ceramic supports were determined with Archimedes' technique. The microstructures of ceramic supports were investigated by using a scanning electron microscope (SEM) (Philips XL 30 SFEG). The particle size distributions of ceramic sols were determined by using the Zetasizer 3000HSA (Malvern Instruments).

\subsection{Filtration experiments}

The separation efficiency and clean water permeability (CWP) of the membranes were determined by using a specially designed filtration system previously described [7]. The CWP values were determined by using deionised water as the feed stream. Feed flux was adjusted as 5 1/min (LPM) and feed temperature was kept constant at $40^{\circ} \mathrm{C}$.

The protein amount in each stream (permeate and retentate) was determined by using the Lowry method (Shimadzu UV-1601 spectrophotometer). The retention values PR and LR (\%) were calculated from PR or LR $(\%)=100 \times\left[1-\left(C_{p} / C_{r}\right)\right]$ where $C_{p}$ and $C_{r}$ are concentrations in the permeate and retentate, respectively [7]. The lactose amount in each stream was determined by using high pressure liquid chromatography (HPLC Perkin Elmer Series 200, Aminex HPX-87H column with a Metatherm column oven). The mobile phase was $5 \mathrm{mM} \mathrm{H}_{2} \mathrm{SO}_{4}$ which was pumped with a flux of $1 \mathrm{ml} / \mathrm{min}$. The column oven temperature was $45^{\circ} \mathrm{C}$.

\section{Results and discussion}

Alumina powder with a relatively higher 

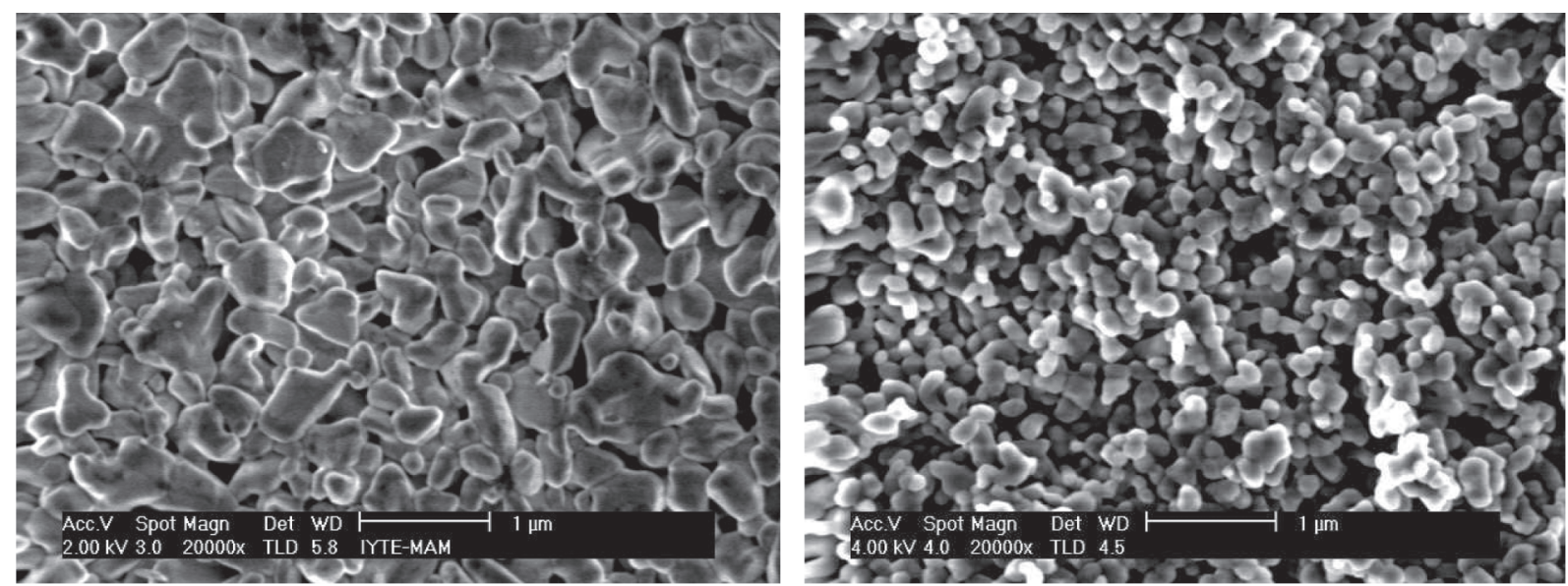

Fig. 1.The top surface SEM micrographs of ceramic supports prepared from coarse (S-2) and fine (on the right) S-1 [7] alumina powders $(20,000 \times)$.

particle size compared to the powders used in previous work [7] was used. The main objective of this choice was to prepare supports with higher CWP and also acceptable mechanical properties. The SEM micrographs of the top surfaces of the ceramic supports prepared from these two alumina powders are shown in Fig. 1. The ceramic supports prepared from the coarser alumina powder with the addition of starch as a pore forming agent caused the formation of $40 \%$ porous supports with $87 \%$ open pores after heat treatment at $1300^{\circ} \mathrm{C}$. The porosity was only $25 \%$ with $49 \%$ open pores without starch addition. The variation of CWP with transmembrane pressure (TMP) for $\mathrm{S}-1$ and $\mathrm{S}-2$ is shown in Fig. 2. The coarser powders formed a microstructure with larger pores which resulted in higher CWP values. There are higher values of CWP reported [1,4,5] for different types of commercial membranes indicating that the value reached with $\mathrm{S}-2$ could be further enhanced. S-2 had sufficient mechanical strength to make it possible to work at higher transmembrane pressures (10 bar) without support failure. Supports prepared from finer powder (S-1) which were heat treated at $1100^{\circ} \mathrm{C}$ failed at these TMP levels.

The particle size distributions of ceramic sols are given in Fig. 3. The mean hydraulic diameters

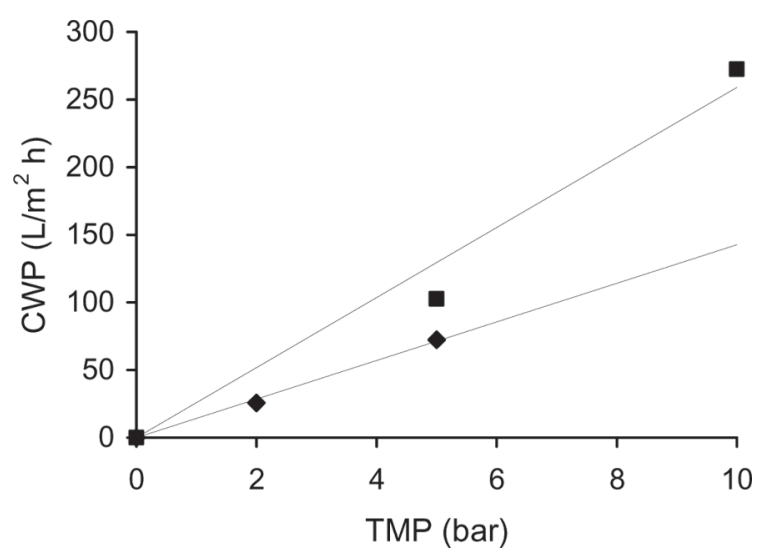

Fig. 2. The variation of ceramic support CWP with TMP prepared from coarse $(\boldsymbol{\square})$ and fine $(\diamond)$ alumina powder.

of fresh and aged zirconia sols were 9 and $35 \mathrm{~nm}$ respectively. The PR of the coarser sol coated membrane (M-2) was around $80 \%$ while it was reported to be higher than $95 \%$ for composite membrane prepared by using zirconia sol with finer particle size (M-1) [7] as shown in Fig. 4. This may be due to the relatively coarser microstructure/pore size of M-2. The protein adsorption may affect ceramic membranes with larger pores more severely as reported by Caric et al. [5]. The initial PR value was lower for M-2 but increased 


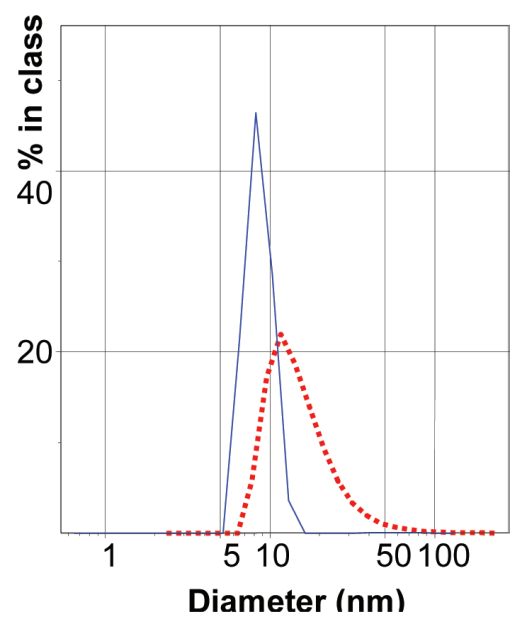

Fig. 3. The volumetric particle size distributions of zirconia sols (solid line: fresh sol, dashed line: aged sol).

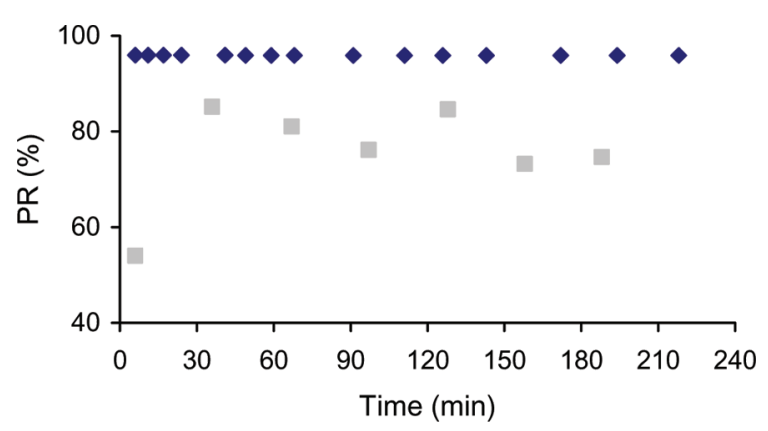

Fig. 4. Protein retention vs. time for composite membranes prepared with sols having mean particle size $9 \mathrm{~nm}$ (M-1) $(\diamond)$ [7] and $35 \mathrm{~nm}(\mathrm{M}-2)(\mathbf{\square})$.

in time indicating the formation of a protein cake layer over the membrane surface.

The variation of permeate flux for the membranes M-1 and M-2 is shown in Fig. 5. The permeate flux decreased from 45 to $35 \mathrm{l} / \mathrm{m}^{2} \mathrm{~h}$ for M-2 in approximately $3 \mathrm{~h}$. It decreased from 80 to $40 \mathrm{l} / \mathrm{m}^{2} \mathrm{~h}$ for M-1 [7]. These values are close to the permeate flux of commercial ceramic multitube MF membranes (around $50 \mathrm{l} / \mathrm{m}^{2} \mathrm{~h}$ for TMP at 5 bar) [4]. Although the permeate fluxes were initially significantly different, they approached one another after about $3 \mathrm{~h}$. The formation of a protein cake layer on the membrane surface may

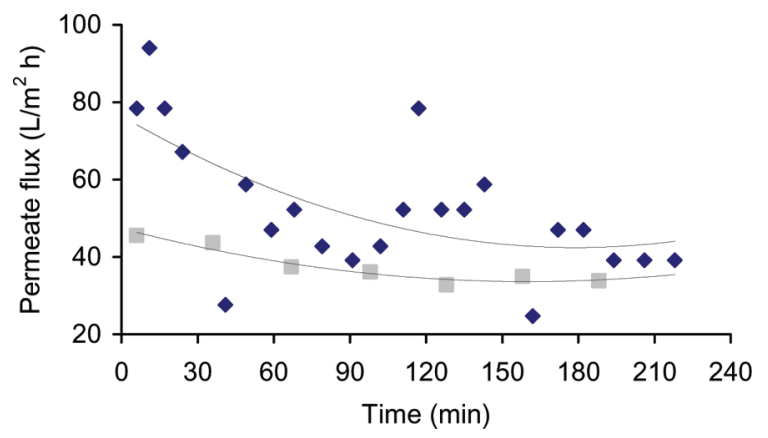

Fig. 5. Permeate flux vs. time for composite membranes prepared with sols having mean particle size $9 \mathrm{~nm}(\mathrm{M}-1)$ $(\bullet)$ [7] and $35 \mathrm{~nm}(\mathrm{M}-2)(\mathbf{\square})$.

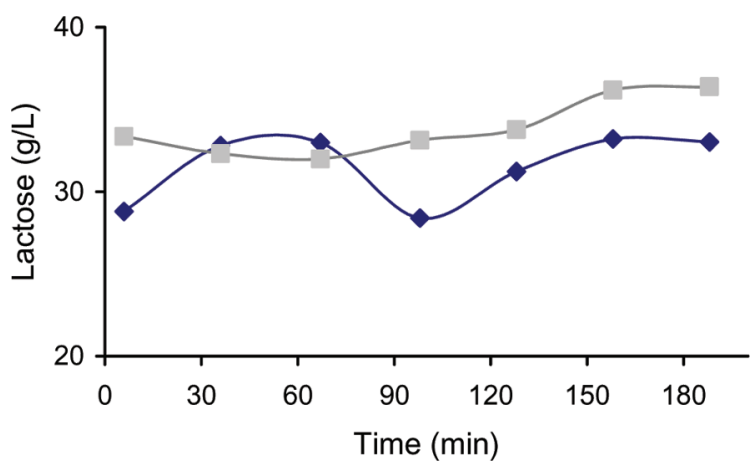

Fig. 6. Permeate $(\bullet)$ and retentate $(\boldsymbol{\square})$ stream lactose contents vs. time for M-2.

have a determining role on the permeate fluxes. The permeate flux for M-2 decreased to a lower value. This may be due to a higher level of protein adsorption/cake formation in this membrane with a relatively higher surface roughness and pore size.

The lactose content of permeate and retentate streams during filtration is given in Fig. 6 for M-2. Higher retentate stream lactose contents were observed especially after $1 \mathrm{~h}$ as shown in Fig. 6 . This low level of lactose retention may be related to the protein cake layer formation being effective as a second selective membrane layer.

The PR value for M-2 ( $80 \%)$ was higher than the values reported for commercial membranes 

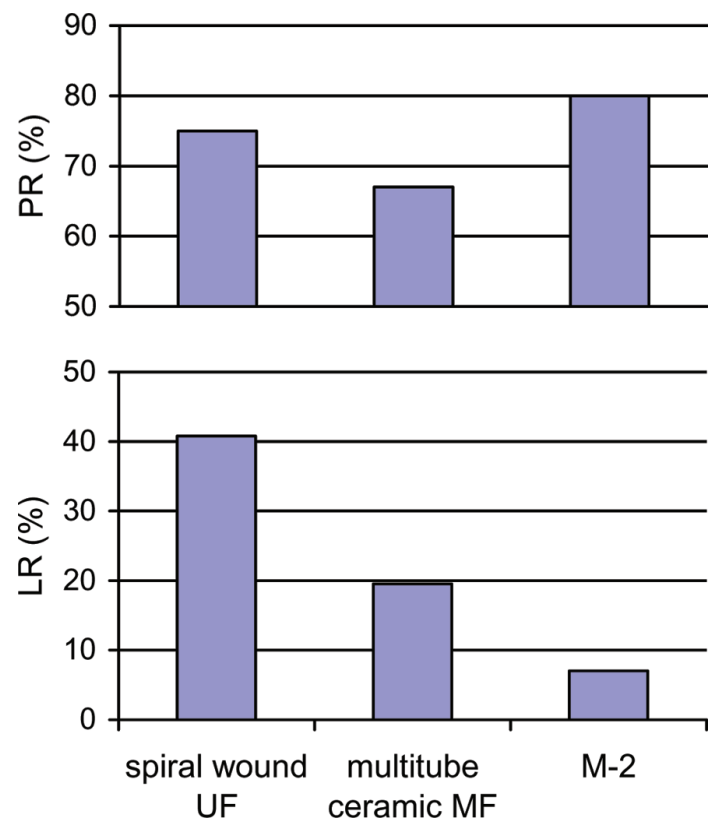

Fig. 7. Protein (PR) and lactose (LR) retention (\%) values for commercial membranes [4] and M-2.

by Rektor and Vatai [4] as shown in Fig. 7. They reported $67 \%$ for ceramic multitube MF membranes and $75 \%$ for spiral wound UF membranes. The lactose in the retentate was $\sim 7 \%$ higher than in permeate for M-2, indicating that a small fraction of lactose was also separated during filtration. The lactose retention values for commercial multitube ceramic MF membrane and spiral wound UF membrane were $19.5 \%$ and $40.8 \%$ [4] respectively as shown in Fig. 7. The composite membrane pre- pared in this work (M-2) has a better lactose and protein separation ability.

\section{Conclusion}

The ceramic composite membrane prepared and characterized in this work (M-2) has a relatively high protein retention/concentration ability (PR 80\%). It also possesses higher protein/ lactose fractionation opportunities with lower lactose retention values (LR $\sim 7 \%$ ). The permeate flux of the membrane was close to that of commercial membranes ( $\sim 01 / \mathrm{m}^{2} \mathrm{~h}$ for TMP at 5 bar). The results of this work indicate the possibility of the preparation of ceramic composite membranes for separation of whey components with higher yields.

\section{References}

[1] R.B. Bhave, Inorganic Membranes: Synthesis, Characteristics, and Applications, Van Nostrand Reinhold, 1991.

[2] M. Cheryan, Ultrafiltration and Microfiltration Handbook, Technomic, Switzerland, 1998.

[3] G. Brans, C.G.P.H. Schroen, R.G.M. Van der Sman and R.M. Boom, J. Membr. Sci., 243 (2004) 263272.

[4] A. Rektor and G. Vatai, Desalination, 162 (2004) 279-286.

[5] M.D. Caric, S.D. Milanovic, D.M. Krstic and M.N Tekic, J. Membr. Sci., 165 (2000) 83-88.

[6] C.J. Brodsky and E.I. Ko, J. Non-Crystalline Solids, 186 (1995) 88-95.

[7] İ. Erdem, M. Çiftçioğlu and Ş. Harsa, Key Eng. Mat., 264-268 (2004), 2251-2254. 